\title{
Planejamento ambiental em uma unidade de conservação no município de Beberibe - Ceará
}

\begin{abstract}
Resumo: O objeto de estudo deste trabalho é o Monumento Natural das Falésias de Beberibe, localizado nas praias de Morro Branco e das Fontes no município de Beberibe - Ceará. Escolheu-se a área do Monumento para estudo devido as suas unidades geoambientais possuírem um grande valor paisagístico, apresentando importância para o litoral, uma vez que são dotadas de fragilidades ambientais. O objetivo principal é uma proposta de planejamento ambiental para a área do Monumento e entorno através de um zoneamento ambiental. $\mathrm{O}$ trabalho foi desenvolvido tendo como base metodológica a Teoria Geossistêmica. As técnicas envolveram a coleta de dados em órgãos, interpretação de imagens do satélite Quickbird (2004), levantamentos de campo e a elaboração de mapas temáticos no software livre Gvsig 1.9. Como resultados delimitaramse uma zona de amortecimento para o Monumento Natural incluindo a faixa de praia e pós-praia, dunas, lagoa do Tracuá e Tabuleiro Pré-litorâneo. Foi proposta a criação da APA da Praia das Fontes e para finalizar um zoneamento ambiental para a área do Monumento Natural abrangendo a sua zona de amortecimento, tendo como seguinte zonas: Intangível, Primitiva, Uso Extensivo e Uso Especial, para a APA da praia das Fontes, as zonas propostas foram: Preservação Ambiental, Conservação Ambiental, Ocorrência Ambiental, Recuperação Ambiental, Ocupação Urbana, Ocupação Especial, Ocupação Residencial e Hoteleira e Expansão Urbana. Este zoneamento poderá ser discutido juntamente com os setores que se encontram envolvidos na área de estudo.
\end{abstract}

\section{Mapping applied to environmental planning in a storage unit in Beberibe- Ceará}

\footnotetext{
Abstract: The object of this paper is the Cliffs National Monument of Beberibe, located on the beaches of Morro Branco and Fontes in Beberibe - Ceará. We chose the area of the Monument for study due to its geo-environmental units have a great landscape value, giving importance to the coast, since they are equipped with environmental weaknesses. The main objective is a proposal for environmental planning for the area around the Monument, and through an environmental zoning. The work was based on methodological Geossistêmica Theory. The techniques involved in data collection agencies, interpretation of Quickbird satellite imagery (2004), field surveys and preparation of thematic maps in open source gvSIG 1.9. As a result delimited to a buffer zone to the Monument including the strip of beach and backshore, dunes, lagoon and Tracuá Tray Precoast. It was suggested that the APA of Praia das Fontes and to finalize an environmental zoning for the area of the Monument covering its buffer zone, with the following areas: Intangible, Early, Extensive Use and Special Use for the APA from the beach sources, the areas proposed were: Environmental Conservation, Environmental Conservation, Environmental Occurrence, Environmental Restoration, Urban Occupation, Occupation Special Residential and Hotel Occupancy and Urban Expansion. This zoning will be discussed along with the sectors that are involved in the study area.
}

Juliana Maria Oliveira Silva *

Edson Vicente da Silva**

* Professora Assistente da Universidade Regional do Cariri (URCA)

**Professor Titular da Universidade Federal do Ceará

\section{Palavras- chave:}

Monumento natural;

Planejamento; Zoneamento ambiental.

Key-Words: Natural Monument; Planning; Zoning; Environmental 


\section{Introdução}

A Geografia é uma ciência voltada ao estudo do espaço e neste, insere-se o homem. Ressaltase que o espaço é dinâmico, seja por causas naturais ou sociais. Sua dinâmica é particularizada em cada lugar e, consequentemente, as paisagens produzidas e reproduzidas nestes lugares são específicas (FALCÃO-SOBRINHO e FALCÃO, 2008).

A Cartografia e o Sensoriamento Remoto são instrumentos técnicos utilizados pela Geografia Física que permitem uma melhor interpretação e representação dos fenômenos que atingem 0 espaço geográfico. Em unidades de conservação a cartografia vem contribuindo para a organização da área através do zoneamento ambiental que está previsto nos planos de manejo. Segundo o SNUC (2000), o zoneamento é a definição de setores ou zonas em uma unidade de conservação, com objetivos de manejo e normas específicos, com o propósito de proporcionar os meios e as condições para que todos os objetivos da unidade possam ser alcançados de forma harmônica e eficaz.

A geografia física tem por objetivo segundo Ross (2006) investigar os fenômenos naturais, sempre inter-relacionados, que se caracterizam por processos dinâmicos de fluxos de energia e matéria entre partes de um todo. Neste sentido, a geografia possui um aparato técnico-metodológico para a elaboração de zoneamentos, já que o mesmo exige o conhecimento de como funciona a dinâmica ambiental para que se possam propor medidas adequadas na área.

Com a cartografia temática é possível obter informações específicas sobre determinado tema ou fenômeno, mostrando sua localização e respectiva distribuição no espaço geográfico. 0 uso do sensoriamento remoto com base na análise de imagens de satélites é um dos meios que se dispõem hoje para acelerar e reduzir custos dos mapeamentos e da detecção de mudanças geoambientais (CAMARGO e SOARES, 2007).

A questão de unidades de conservação vem sendo bastante trabalhada por geógrafos, que estão fornecendo diagnósticos ambientais atualizados e propostas de gestão para as UC's através de zoneamentos que poderão subsidiar a elaboração de planos de manejo. Oliveira e Marques (2003) comentam que a temática é recente, estando longe de se esgotar. É necessário que os geógrafos também se insiram neste estudo, pois tais profissionais podem realizar uma conexão entre "físico" e "humano" de forma ímpar. É necessário que nos façamos mais presentes neste campo que carece de informações, sobretudo no tocante à distribuição espacial.

Os campos de conhecimento da Geografia Física como a geomorfologia, hidrologia e biogeografia em muito contribuem para os estudos em unidades de conservação. Guerra e Marçal (2006) explicam que os conhecimentos geomorfológicos estão beneficiando as UC's no Brasil, atuando na recuperação de áreas degradas, definição de trilhas e de áreas a serem melhor aproveitadas, através do estabelecimento das suas capacidades de suporte.

O objeto de estudo deste trabalho, o Monumento Natural das Falésias de Beberibe, localizase no município de Beberibe (figura 01), litoral leste do Estado do Ceará, entre as praias de Morro Branco e das Fontes, possuindo uma área de 31,2 hectares e um perímetro 5.709 metros. Criado em junho de 2004 devido a sua beleza cênica que atrai muitos visitantes, o Monumento Natural tem por objetivo a sua proteção contra os impactos ambientais que ocorriam anteriormente nas falésias, antes do decreto de sua instituição como unidade de conservação. A unidade de conservação do tipo Monumento Natural (objeto deste trabalho) é integrante do grupo de Proteção Integral, tendo

Geografia Ensino \& Pesquisa, v. 16, n.2 p. 129 - 145, maio/ago. 2012

Planejamento ambiental em uma unidade de conservação no município de Beberibe - Ceará

130

ISSN 2236-4994 por objetivo preservar sítios naturais raros, singulares ou de grande beleza cênica.

As falésias do Monumento Natural são as únicas que estão protegidas e não possuem ocupações, enquanto que as outras como as da Praia das Fontes são ocupadas por hotéis e casas de veraneio, é como se o Monumento Natural fosse um "ilha" em meio a tantas ocupações presentes ao seu redor. Todo o entorno geográfico que abrange as falésias de Beberibe necessita de um ordenamento de uso e ocupação do solo adequado aos seus limites (SILVA, 2008). Por conseguinte, achou-se interessante incluir na pesquisa não só as falésias locais, mas outras 
unidades geoambientais (praia, campos de dunas, planícies lacustres e as falésias que estão fora da delimitação do Monumento Natural e que são ocupadas na Praia das Fontes) que formam o conjunto do entorno geográfico da área estudada. 0 objetivo principal deste trabalho é uma proposta de planejamento ambiental para a área do Monumento e entorno através de um zoneamento ambiental.

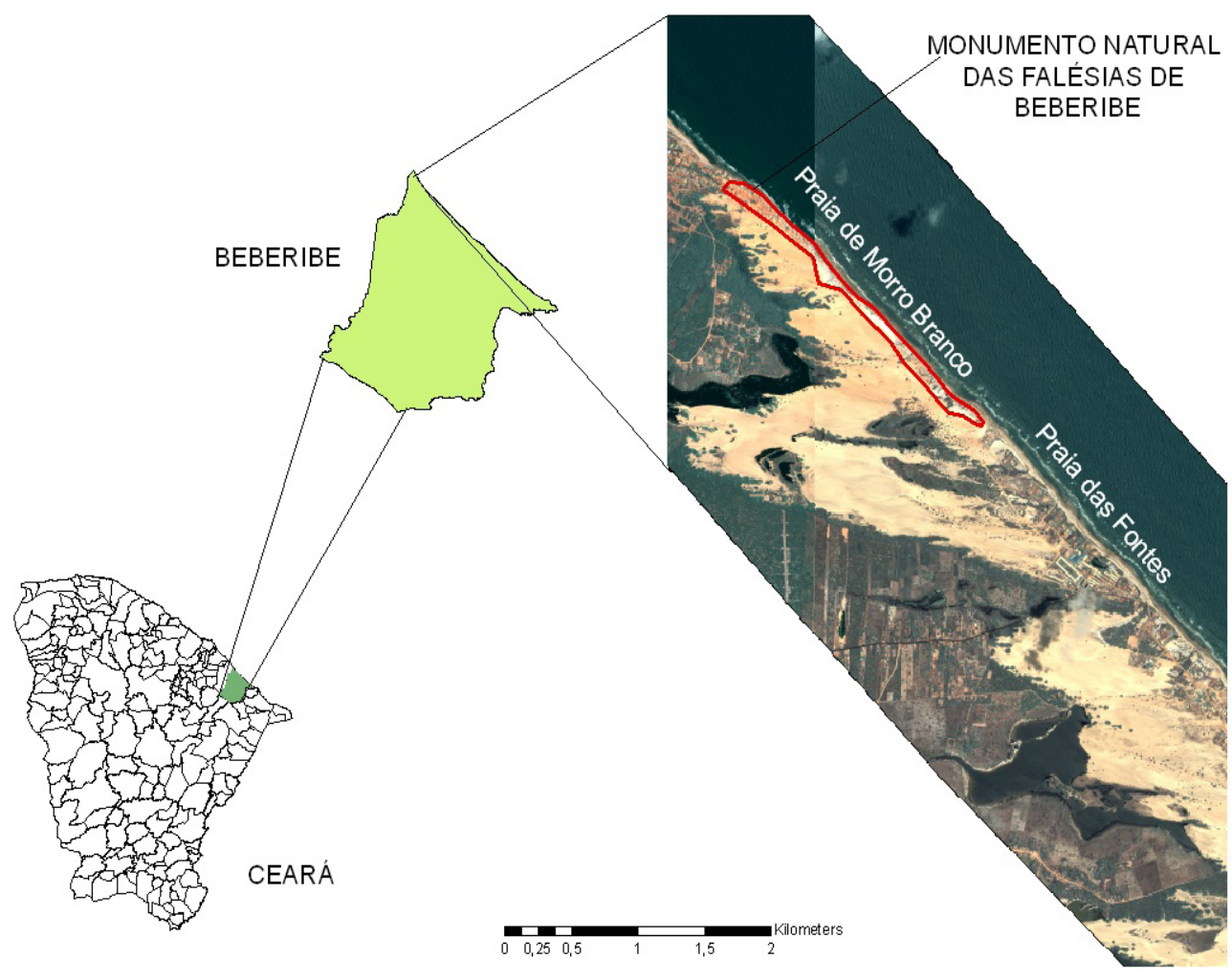

Figura 01- Localização da área de estudo

\section{Material e Métodos}

O trabalho teve como base metodológica a Análise Geossistêmica, trabalhando autores como Bertrand (1972), Ross (2006).

A Teoria Geossistêmica foi um marco fundamental para os estudos geográficos voltados ao planejamento ambiental, diagnósticos do meio físico, conhecimentos dos aspectos socioambientais de um local, pois, esta teoria permite ao pesquisador uma visão conjunta, interdisciplinar sobre a paisagem. A fundamentação teórica permitiu um aprofundamento do trabalho, onde foi possível organizar as idéias teóricas que foram posteriormente colocadas em prática durante as análises efetuadas na área de estudo.

Um zoneamento ambiental pode ser definido como sendo a identificação e a delimitação de unidades ambientais em um certo espaço físico, segundo suas vocações e fragilidades, acertos e conflitos, determinadas a partir dos elementos que compõem o meio planejado, tendo como resultado a apresentação de um conjunto de unidades, cada qual sujeita às normas especificas para o desenvolvimento de atividades e para a conservação do meio (SANTOS, 2004).

Todo processo de pesquisa necessita de técnicas que possibilitarão o desenvolvimento do trabalho e para isso, o trabalho seguiu alguns procedimentos técnicos que permitiu chegar aos resultados da pesquisa.

Geografia Ensino \& Pesquisa, v. 16, n.2 p. 129- 145, maio/ago. 2012

Silva, J. M. O.; Silva, E. V. 
A pesquisa se dividiu em dois momentos distintos: a etapa de laboratório e os levantamentos de campo.

A etapa de laboratório se dividiu em três momentos distintos:

- Levantamentos bibliográficos;

- Utilização de técnicas de Sensoriamento Remoto e Cartografia;

- Organização dos resultados coletados em campo.

O zoneamento ambiental da área teve como base o Roteiro Metodológico de Planejamento de Unidades de Conservação de Uso Indireto (Parque Nacional, Estação Ecológica e Reserva Biológica), elaborado pelo IBAMA (2001). Não se tem um documento específico em nível federal ou estadual que regule o planejamento do Monumento Natural, pois este tipo de Unidade de Conservação pode ser constituído de área particular. Como a área de estudo é administrada pelo Estado e é de Uso Indireto, optou-se por utilizar a metodologia do documento elaborado pelo IBAMA (2002). Outras metodologias trabalhadas por autores como IBAMA (2001), CARDOSO (2002) e VIDAL (2006) foram aplicadas para a proposta de zoneamento do entorno da área que está fora da delimitação do Monumento Natural, onde foi proposta uma APA para a Praia das Fontes. Foram utilizados os seguintes materiais cartográficos e de sensoriamento remoto:

- Mapa básico de Beberibe adquirido digitalmente pelo IDACE (Instituto de Desenvolvimento Agrário do Ceará na escala de 1:100.000); (2003);

- Mapa Geológico e Geomorfológico do Estado do Ceará na escala 1:500.000 da CPRM

- Imagens do Quickbird com resolução espacial de 60cm do ano de 2004 da SEMACE (Superintendência Estadual do Meio Ambiente).

A interpretação das imagens e a vetorização foram realizadas com o auxílio do software livre Gvsig 1.9 desenvolvido pela Universidade de Valência (Espanha). Para a delimitação das unidades geoambientais utilizou-se como critério a geomorfologia, pois as formas de relevo são mais facilmente identificadas e levantamentos de campo. Segundo Soares (1998):

O destaque feito à geomorfologia como fator básico de integração é devido tanto ao seu grau de "estabilidade" como pela maior facilidade de se identificar, delimitar e interpretar os comportamentos topográficos e as funções de modelado nele contido e conduzir a uma condição parcial de integração através das condições morfo-estruturais, morfopedológicos, morfo-climáticos e hidro-morfológicos.

Geografia Ensino \& Pesquisa, v. 16, n.2 p. 129 - 145, maio/ago. 2012

\footnotetext{
Planejamento ambiental em uma unidade de conservação no município de Beberibe - Ceará
}

\section{Resultados e discusões}

\section{Unidades Geoambientais da área do Monumento Natural}

A unidade geoambiental compreende uma unidade de paisagem que tem feições mais ou menos homogêneas, ocupando uma determinada porção da superfície terrestre, e revelando um conjunto de características físicas e bióticas próprias (SILVA et al, 2004).

As unidades geoambientais encontradas na área de estudo foram o mar litorâneo, planície litorânea (faixa de praia, pós-praia, campos de dunas e planícies lacustres) e tabuleiro pré-litorâneo (falésias) e podem ser visualizadas na figura 01.

\section{Mar Litorâneo}

O mar litorâneo é uma área do oceano que está junto ao continente e na área de estudo o mar litorâneo encontra-se ao Norte. A flora presente nesta unidade é composta basicamente de fitoplanctons que servem de alimentos para a fauna presente como os peixes, moluscos e crustáceos. 


\section{Planície Litorânea \\ Faixa de praia e pós-praia}

A faixa de praia da área estudada (figura 02) é recoberta por sedimentos constituídos por areias quartzozas, com grande acumulação e depositados pelo mar. As ondas atacam obliquamente à praia com direção SE-NW, originando assim o transporte longitudinal de areia, principalmente na zona de surf. A fonte de sedimentos são as areias vindas do continente transportados pelos rios e da ação erosiva das ondas nas falésias.

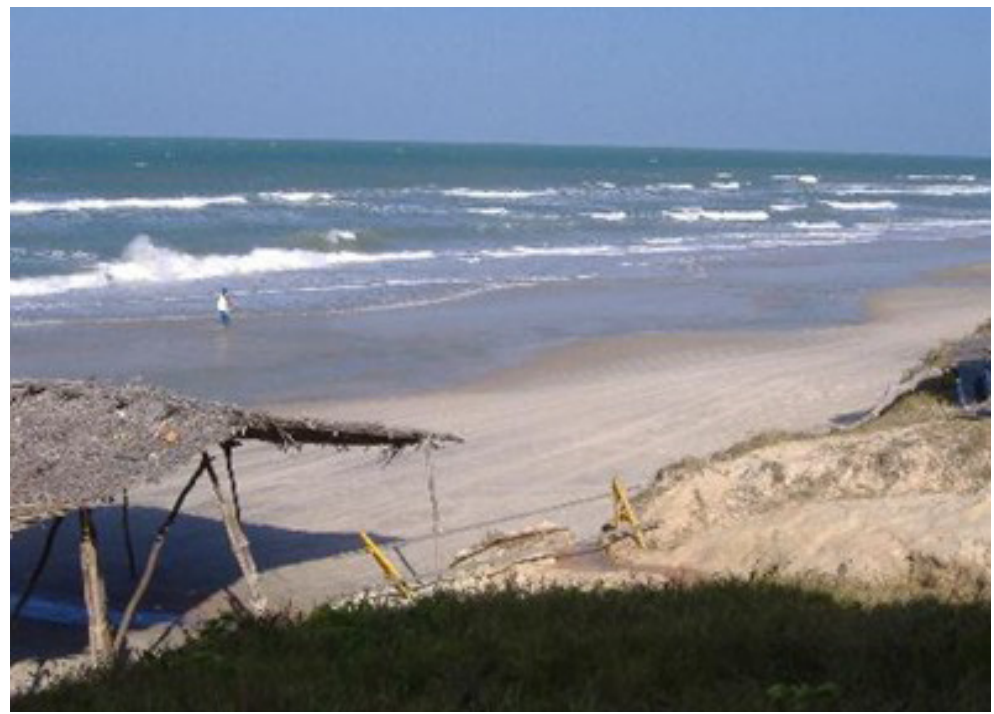

Figura 02- Faixa de Praia

Em alguns setores da faixa de praia há a presença de plataforma de abrasão marinha formada pela ação das ondas e marés nas falésias em períodos tércio-quaternário. A pós-praia da área aparece em apenas alguns setores da praia de Morro Branco, antes do início do Monumento Natural das Falésias, e aparece novamente no final desta Unidade de Conservação, no início da Praia das Fontes, mas ocupando um curto espaço, pois as falésias começam a aflorar novamente na praia, impossibilitando a formação de pós-praia. As principais espécies de vegetação encontrada na pós-praia da área de estudo são Ipomea pes-caprae (salsa) e Remirea marítima (pinheirinhoda-praia).

\section{Campos de Dunas}

$\mathrm{Na}$ área de estudo, as dunas (figura 03) dispõem-se à retaguarda das falésias sendo formadas por areias quartzozas esbranquiçadas, amareladas e alaranjadas, de granulação média a fina. A fonte destes sedimentos são as areias depositadas na faixa de praia e da erosão das falésias.

Em relação ao grau de consolidação, as dunas móveis e fixas se destacam na paisagem. As móveis se localizam depois das falésias, com vegetação em processo de consolidação, mas sua disposição favorece a migração dos sedimentos. Ocorrendo mais no interior após as dunas móveis, podem-se encontrar as dunas fixas.

Outra feição presente na área são os corredores de deflação, que são áreas planas e deprimidas que separam as dunas presentes na praia das que se situam mais no interior. Estas formas permitem a passagem de sedimentos para alimentar outras dunas. 


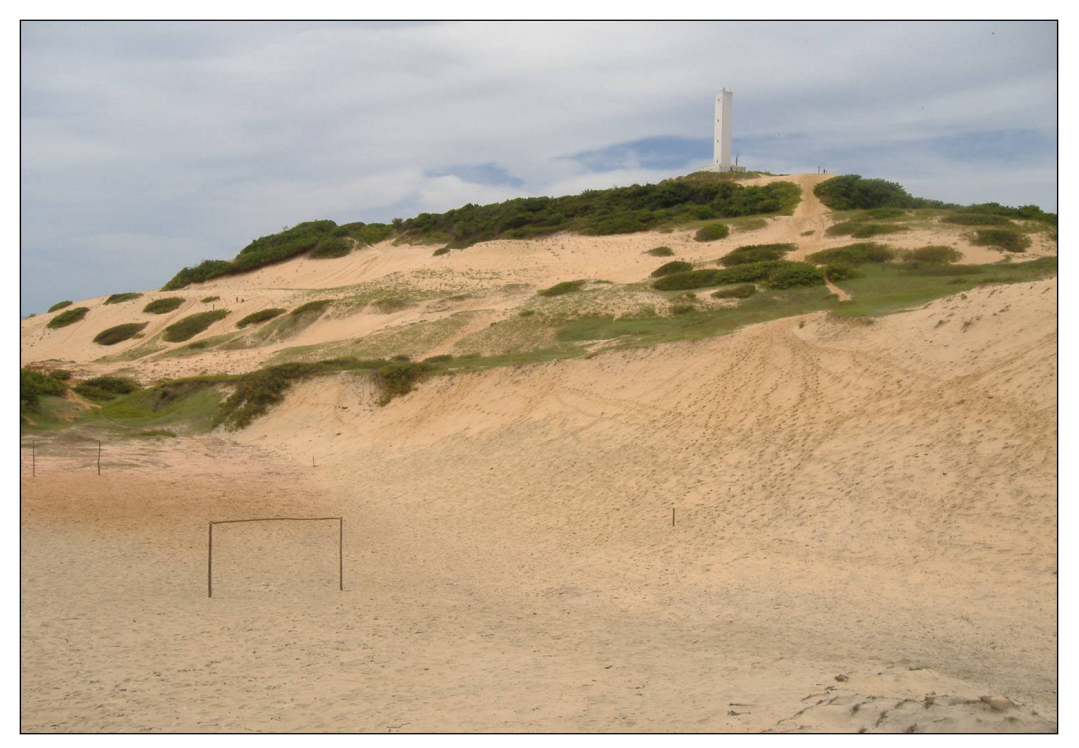

Figura 03- Início do campo de dunas

\section{Planície Flúvio-Lacustre}

As planícies flúvio-lacustre são áreas que se desenvolvem às margens de lagoas e ocorrem por todo o litoral com dimensões variadas.

$\mathrm{Na}$ área de estudo identifica-se duas lagoas sendo perenes (Lagoa do Tracuá e Uberaba) e outras intermitentes. A lagoa do Tracuá (figura 04) possui uma área em torno de 24 hectares e a Uberaba (figura 05) 60 hectares.

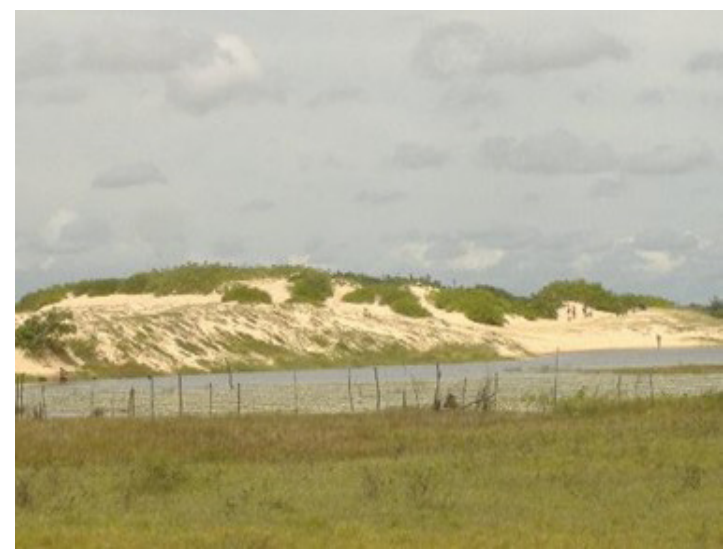

Figura 04- Lagoa do Tracuá - Praia de Morro Branco

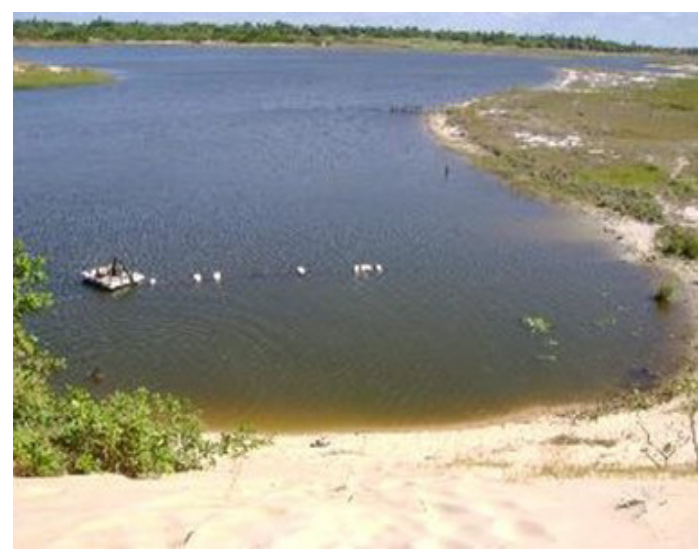

Figura 05- Lagoa da Uberaba
Geografia Ensino \& Pesquisa, v. 16, n.2 p. 129 - 145, maio/ago. 2012

Planejamento ambiental em uma unidade de conservação no município de Beberibe - Ceará

\section{Tabuleiros pré-litorâneos (falésias)}

Os tabuleiros pré-litorâneos são modelados nos sedimentos da Formação Barreiras, com sedimentos areno-argilosos de idade tércio-quaternário com granulação de fina a média, com cores que variam do branco ao amarelo e vermelho.

$\mathrm{Na}$ área de estudo, o tabuleiro pré-litorâneo que aflora na linha de costa sob forma de falésia é a principal unidade geoambiental da área de estudo, pois a unidade de conservação em estudo, tem como elemento principal as falésias.

As falésias da área (figura 06) tem uma extensão longitudinal de aproximadamente $6 \mathrm{Km}$. Apresentam formas em pleno processo denudacional, porque estão topograficamente elevadas em relação à linha de costa. A maior parte delas são denominadas vivas, pois sofrem a influência da abrasão marinha na base, e no topo a erosão pluvial e eólica atuam nas suas estruturas. 
Apresentam voçorocas, sendo que entre elas brotam inúmeras fontes de água que escoam para o mar. Na plataforma de abrasão as ondas chegam e a atingem diretamente, remobilizando os sedimentos inconsolidados.

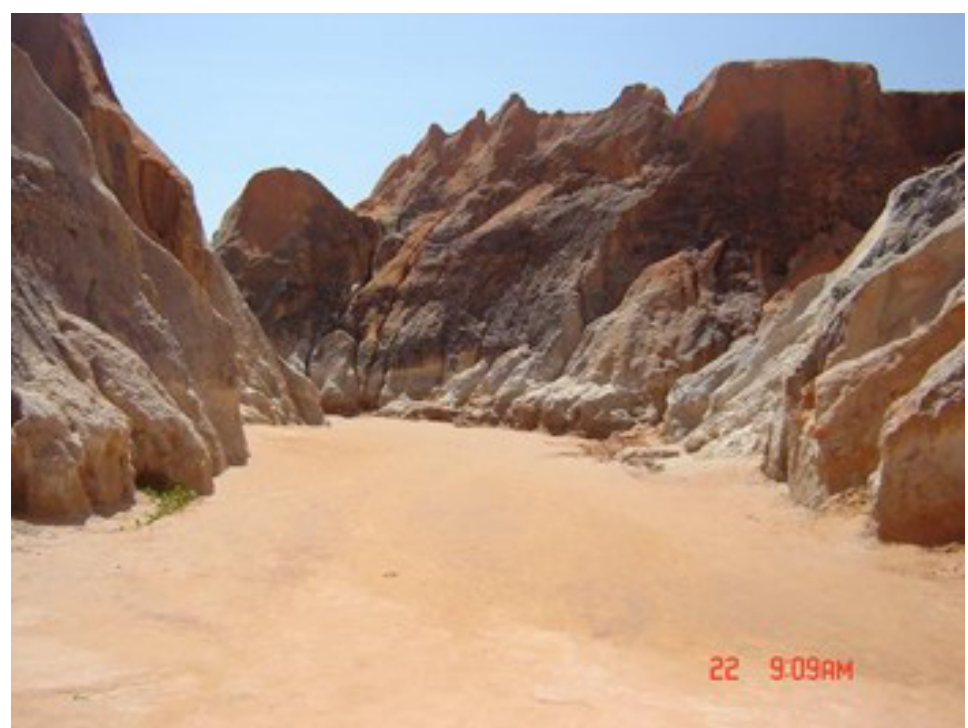

Figura 06- Falésias

$\mathrm{Na}$ área de estudo as falésias se estendem por 18 hectares (falésias pertencentes ao Monumento Natural) e 12 hectares (falésias fora da delimitação do Monumento Natural). Percebese um intenso trabalho erosivo nas escarpas, formando voçorocas. No período chuvoso, a ação erosiva é bem maior, ocorrendo deslizamentos de sedimentos e desprendimentos de blocos.

$O$ ataque constante das ondas vai aos poucos desgastando o material e formando buracos na estrutura dos paredões. Uma famosa estrutura morfológica é a Gruta da Mãe D'água (figura 07) na praia das Fontes. Ao longo do tempo a força das ondas foi moldando as falésias até que se abriu uma "caverna" e que hoje é muito visitada pelas pessoas.

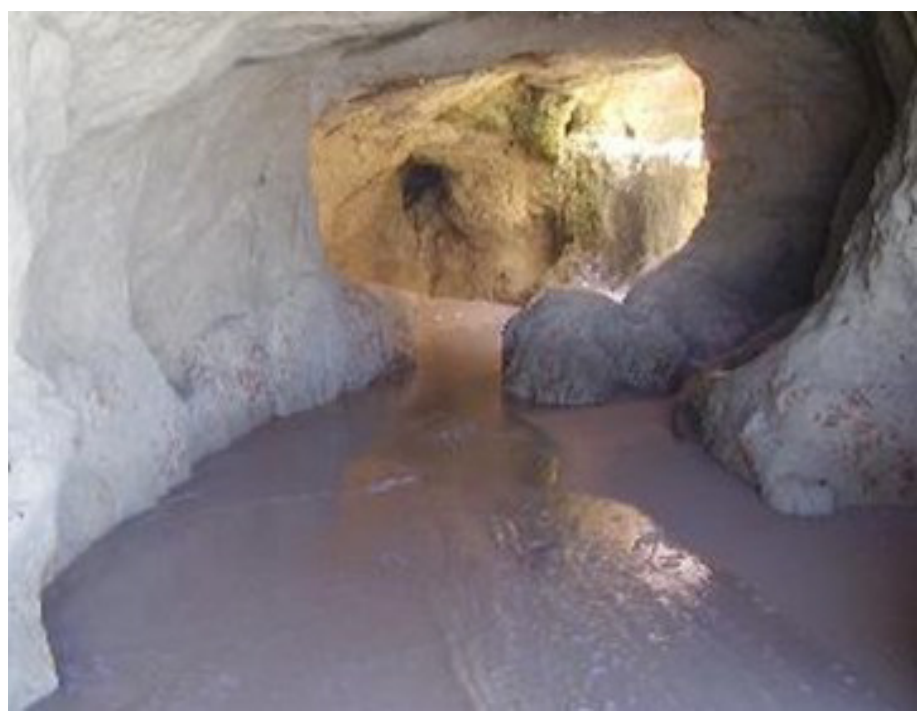

Figura 07- Gruta da Mãe

A Gruta da Mãe d'água expõe uma bela estrutura, mas não podemos deixar de mencionar 0 risco de desabamento, pois a parte escavada está suportando o material sobrejacente que existe até que um dia pela força da gravidade o material desabará. Outra nota importante é que a gruta não está inserida na delimitação do Monumento Natural, ficando sujeita à degradação.

Geografia Ensino \& Pesquisa, v. 16, n.2 p. 129-145, maio/ago. 2012

Silva, J. M. O.; Silva, E. V. 
No contato da camada argilosa com a arenosa surgem as famosas fontes de águas. Encontram-se pelos menos 16 ressurgências, sendo algumas de grande expressão e outros filetes de águas que escorrem constantemente das falésias. As mais famosas são a Bica das Virgens (no Morro Branco), a Fonte Raimundo Fagner (na praia das Fontes), Sangradouro das Fontes (praia das Fontes), e outras duas (sem denominação), são as mais aproveitadas por possuírem um volume maior de despejo de água.

\section{Proposta de zoneamento ambiental}

A área de estudo possui muitas particularidades locais, no que se refere ao seu grau de conservação dos recursos naturais e localização dos problemas ambientais como as ocupações desordenadas. Pensando nisto, se propôs múltiplos usos para a área estudada.

Inicialmente delimitou-se uma Zona de Amortecimento para o Monumento Natural, identificando-se a sua área e a importância de cada setor para a zona de amortecimento da unidade de conservação. O SNUC (2000) definiu a zona de amortecimento como sendo o entorno de uma unidade de conservação, onde as atividades humanas estão sujeitas a normas e restrições específicas, com o propósito de minimizar os impactos negativos sobre a unidade. Para a praia das Fontes se propuseram medidas diferenciadas da Unidade de Conservação estudada, uma vez que essa praia não está incluída totalmente na delimitação do Monumento Natural. Posterior à proposta de APA da Praia das Fontes, um zoneamento ambiental foi traçado para o Monumento Natural e sua respectiva zona de amortecimento, de acordo com os critérios para as unidades de proteção integral e um zoneamento para a APA de acordo com a metodologia proposta pelo IBAMA (2002) para as APA's.

\section{Uma proposta de delimitação da Zona de Amortecimento}

A Zona de Amortecimento é de extrema importância para as unidades de conservação, pois ajudam na proteção dos recursos naturais que envolvem a unidade de conservação. As únicas categorias que não tem uma zona de amortecimento recomendada são as Áreas de Proteção Ambiental (APA) e Reserva Particular do Patrimônio Natural (RPPN). Outra observação importante é que o SNUC prevê que a zona de amortecimento uma vez definida não poderá ser transformada em áreas urbanas.

O IBAMA (2001) estabeleceu alguns critérios para a inclusão da zona de amortecimento em áreas de proteção integral. De acordo com as proposições adotadas pelo IBAMA (2001), traçouse uma possível zona de amortecimento. A seguir lista-se os critérios que foram utilizados na delimitação, de acordo com as particularidades da área.

- Áreas de recarga de aqüíferos;

- Áreas naturais preservadas com potencial de conectividade com a unidade de conservação (APP, RL, RPPN e outras);

- Áreas sujeitas a processos de erosão, de escorregamento que possam vir a afetar a integridade da UC;

- Áreas com risco de expansão urbana ou presença de construções que afetem aspectos

Geografia Ensino \& Pesquisa, v. 16, n.2 p. 129 - 145, maio/ago. 2012

Planejamento ambiental em uma unidade de conservação no município de Beberibe - Ceará paisagísticos notáveis junto os limites da UC;

- Ocorrência de acidentes geográficos e geológicos notáveis ou aspectos cênicos próximos à UC.

Estes critérios foram fundamentais, para a delimitação da zona de amortecimento do Monumento das Falésias, desta forma foi possível delimitá-la, como pode ser visualizada na figura 08 de delimitação da zona de amortecimento da área. Incluíram-se as seguintes paisagens na zona de amortecimento: faixa de praia e pós-praia, dunas, lagoa do Tracuá e Tabuleiro Pré-litorâneo. 
Faixa de Praia / Pós-Praia: Localizada ao Norte do Monumento Natural. Esta área apresenta importância para a dinâmica e evolução do sistema litorâneo que envolve a unidade de conservação.

Se houver alguma modificação na faixa de praia, os processos erosivos aumentarão e com isso as falésias vão acabar sendo erodidas mais fortemente. Dentre os critérios do IBAMA (2002), que fizeram com que a faixa de praia fosse escolhida, está que ela é uma área sujeita a erosão, fazendo com que o desequilíbrio ambiental desta área, a unidade de conservação poderá ser prejudicada. Ressaltando-se ainda a faixa de praia possui um elevado valor cênico que está muito próxima à UC. A área de praia e pós-praia que será incorporada a zona de amortecimento é de 10 hectares.

Campos de Dunas: Esta área localiza-se a retaguarda das falésias. Possui muitos critérios que foram essenciais para a inclusão desta unidade na zona de amortecimento. É importante observar que apenas uma pequena parte das dunas móveis está incluída na demarcação do Monumento Natural, mas a sua maior parte está fora desta delimitação. Por isso é necessário que se inclua toda a área das dunas móveis que se encontram atrás das falésias pertencentes ao Monumento Natural, pois uma vez que estas dunas móveis se encontrarem protegidas, consequentemente as falésias também estarão.

As dunas são ameaçadas constantemente pela ocupação residencial se as dunas forem ocupadas, o Monumento ficará então totalmente circundado por casas, o que poderá prejudicar a sua integridade. As dunas também ficarão protegidas de novas construções como as que ocorreram na Praia das Fontes no caso do último hotel que foi construído e do condomínio de luxo instalado entre as dunas e o tabuleiro,

As dunas móveis e fixas foram as unidades que mais se enquadraram nos critérios adotados para a delimitação da zona de amortecimento. Estas unidades geomorfológicas são áreas de recarga de aqüíferos, estando protegidas pela resolução do CONAMA como áreas naturais preservadas do tipo APP, possuindo aspectos cênicos de grande relevância nas proximidades da UC. Ressalta-se que são áreas com risco de expansão urbana. Se acontecer as ocupações, vai comprometer não só as dunas, mas os aspectos paisagísticos junto aos limites da UC. A área das dunas delimitadas zona de amortecimento tem uma área de 214 hectares.

Planície da Lagoa do Tracuá: Esta unidade se encontra logo após das dunas fixas, e que incluída na zona de amortecimento ela poderá dar continuidade nas interrelações geoambientais da área.

A lagoa mantém uma conectividade com as dunas móveis e fixas que se localizam próximas a ela. As dunas têm uma importância na dinâmica da lagoa, uma vez que estas são responsáveis pela a alimentação hídrica da lagoa. A vegetação que margeiam a lagoa é também protegida pela legislação como APP.

Tabuleiro Pré-litorâneo: 0 tabuleiro foi incluso por ser mais uma área que atua como uma recarga de aqüifero e mantém uma conectividade com os recursos hídricos superficiais, principalmente com a lagoa do Tracuá. A comunidade local utiliza a área para as suas atividades extrativistas.

Do ponto de vista de sua estabilidade é satisfatória, mas não significa que suas atividades não devam ser monitoradas. É preciso um disciplinamento do uso do tabuleiro para que esta unidade não venha a ser utilizada de forma que possam comprometer a sua integridade. A área do tabuleiro na zona de amortecimento é de 102 hectares.

Todas estas unidades possuem uma conectividade entre si e são responsáveis pela manutenção da dinâmica geoambiental da área, proporcionando tanto o bem estar ambiental da unidade de conservação como para 0 entorno da área. Ainda oferecem uma produtividade socioeconômica para as comunidades que habitam ao redor das unidades.

Aárea urbana da comunidade do Morro Branco, como é o portão de entrada para o Monumento Natural, deverá ter suas atividades reguladas. A comunidade poderá atuar juntamente com a administração da UC na regulação das atividades. Já se tem uma placa na entrada da comunidade

Geografia Ensino \& Pesquisa, v. 16, n.2 p. 129- 145, maio/ago. 2012

Silva, J. M. O.; Silva, E. V. 
informando que naquela área todos os empreendimentos deverão passar por regulamentação para serem liberados.

\section{Praia das Fontes: proposta de criação de uma APA.}

As falésias da praia das Fontes não podem se tornar uma ampliação do Monumento Natural, porque as mesmas já se encontram parcialmente ocupadas e a categoria de Monumento Natural como Proteção Integral não pode conter ocupações em sua área. Somente uma parte das falésias da Praia das Fontes não está ocupada: no começo da praia (estas pertencem ao Monumento Natural - indicam o final do Monumento) e a Gruta da Mãe D'água (no meio da praia).

Diante deste panorama, propõe-se a criação de uma Área de Proteção Ambiental da Praia das Fontes. AAPA poderá ser administrada pela Prefeitura Municipal de Beberibe. Com a criação e gerenciamento da APA, a comunidade ficará mais protegida do avanço da especulação imobiliária, já que a APA impõe restrições de uso e ocupação do solo. Segundo a definição do SNUC (2000), no Capítulo 03, artigo XV, a APA é:

"Uma área em geral extensa, com um certo grau de ocupação humana, dotada de atributos abióticos, bióticos, estéticos ou culturais especialmente importantes para a qualidade de vida e o bem-estar das populações humanas (SNUC, 2000: 07) ".

A APA foi a categoria de unidade de conservação que mais se enquadrou para a Praia das Fontes, devido principalmente aos seus objetivos de disciplinar o processo de ocupação, e providencial para a praia das Fontes. A APA (a sua área de abrangência pode ser visualizada na figura 08) incluiu a comunidade, seus recursos naturais como a faixa de praia, falésias, dunas, lagoas e o tabuleiro pré-litorâneo, onde está localizada a comunidade do Onofre.

Geografia Ensino \& Pesquisa, v. 16, n.2 p. 129 - 145, maio/ago. 2012

Planejamento ambiental em uma unidade de conservação no município de Beberibe - Ceará

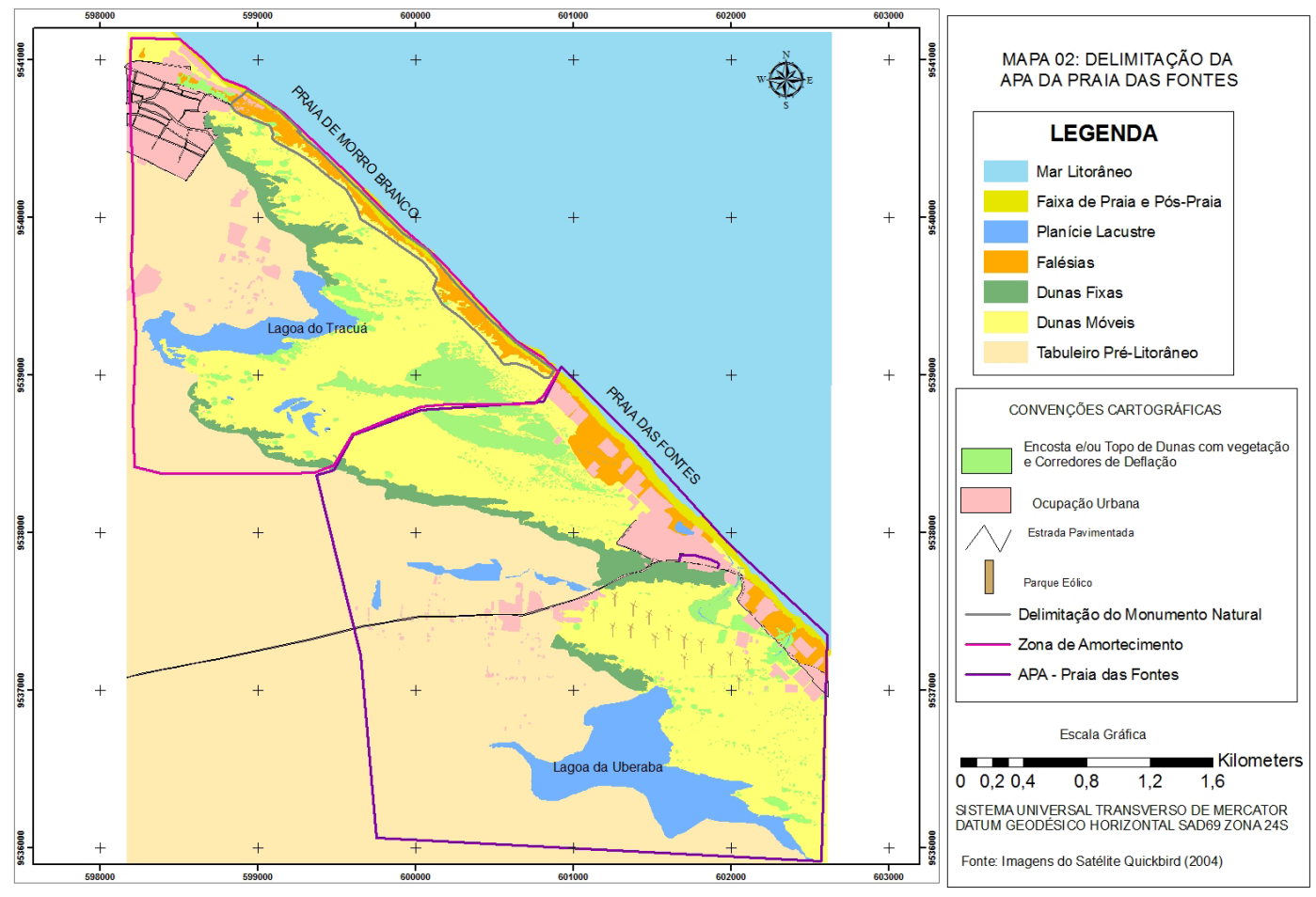

Figura 08- Delimitação da zona de amortecimento do Monumento Natural e da APA da Praia das Fontes 


\section{Zoneamento Ambiental}

O zoneamento ambiental é um instrumento que faz parte de todo um planejamento que se queira aplicar em determinado local e que a gestão poderá colocá-lo em prática. Aqui se pretende adotar um zoneamento ambiental para a unidade de conservação, o que é previsto pela legislação. Como se abordou na metodologia, adotou-se os critérios do Roteiro Metodológico de Planejamento elaborado pelo IBAMA (2001) para as unidades de proteção integral. Na figura 09 visualiza-se o zoneamento feito para o Monumento Natural e zona de amortecimento como também para a proposta de APA da Praia das Fontes.

O Zoneamento Ambiental (Lei $n^{0} 6938$ de 31/08/1981) prevê preservação, reabilitação e recuperação da qualidade ambiental. Sua meta é o desenvolvimento socioeconômico condicionado à manutenção, em longo prazo, dos recursos naturais e melhoria das condições de vida do homem (SANTOS, 2004).

\section{Zoneamento Ambiental do Monumento Natural das Falésias e sua Zona de Amortecimento.}

O Zoneamento Ambiental do Monumento Natural incluiu a sua zona de amortecimento, pois não basta que a área do Monumento Natural esteja protegida, mas todo o mosaico que compõe sua área e a zona de amortecimento deverá entrar no zoneamento. A seguir estão as zonas propostas com suas unidades geoambientais incluídas, com áreas de cada zona e tipo de uso recomendado, tudo de acordo com as recomendações do IBAMA (2002).

Zona Intangível (ZI): Esta zona apresenta o mais alto grau de preservação, não podendo conter alterações humanas. Para o IBAMA (2002), esta zona é dedicada à proteção integral de ecossistemas dos recursos genéticos e ao monitoramento ambiental. $O$ objetivo básico do manejo é a preservação, garantindo a evolução natural.

São as normas gerais nesta área, segundo o Roteiro Metodológico do IBAMA (2002):

- Pesquisa restritiva (quando impossível de ser realizada em outras zonas da Unidade);

- A fiscalização será eventual, em casos de necessidade de proteção da zona, contra as formas de degradação;

- Não serão permitidas quaisquer instalações de infra-estrutura;

- Não serão permitidos deslocamentos em veículos motorizados;

- Não será permitida a visitação a qualquer título.

Para esta zona recomenda-se a inclusão das falésias localizadas após o labirinto, até o final do Monumento, pois é uma área que não ocorrem visitas (as visitas são feitas somente no Labirinto), e a área tem falésias bem preservadas. A zona intangível abrangeria uma área de 10,8 hectares.

Zona Primitiva (ZP): É onde se tenha ocorrido uma mínima intervenção humana, com fenômenos de grande valor científico.

Deve possuir características de transição entre a zona Intangível e a Zona de Uso Extensivo. 0 objetivo geral do manejo é a preservação do ambiente natural e ao mesmo tempo facilitar as atividades de pesquisa científica e educação ambiental permitindo-se formas primitivas de recreação (IBAMA, 2002).

As normas gerais para esta área são:

- Pesquisa, monitoramento ambiental, a visitação e a fiscalização;

- A interpretação dos atributos desta zona se dará somente através de folhetos e/ou recursos indiretos, inclusive aqueles oferecidos no Centro de Visitantes;

- As atividades permitidas não poderão comprometer a integridade dos recursos naturais;

- Os visitantes, pesquisadores e o pessoal da fiscalização serão advertidos para não deixarem lixo nesta área.

Geografia Ensino \& Pesquisa, v. 16, n.2 p. 129- 145, maio/ago. 2012

Silva, J. M. O.; Silva, E. V. 
- É proibido o tráfego de veículos nesta zona, exceto em ocasiões especiais, em casos de necessidade de proteção da Unidade.

- A fiscalização será constante na área.

As dunas móveis e fixas ficarão nesta zona, pois houve pouca alteração humana, apenas a construção do farol e algumas trilhas utilizadas pela população local. E a sua localização é mesmo na transição da Zona Intangível e a de Uso Extensivo. A Zona Primitiva tem uma área de 214 hectares.

Zona de Uso Extensivo (ZUE): Segundo o IBAMA (2002) é uma zona constituída em sua maior parte por áreas naturais, podendo apresentar algumas alterações humanas. 0 objetivo de manejo é a manutenção de um ambiente natural com mínimo impacto humano, apesar de oferecer acesso aos públicos com facilidade, para fins educativos e recreativos.

Dentre as normas gerais, destaca-se:

- A pesquisa científica, visitação, fiscalização e monitoramento ambiental,

- Instalação de equipamentos simples para a interpretação dos recursos naturais e a recreação, sempre em harmonia com a paisagem;

- Esta zona será constantemente fiscalizada;

- Trânsito de veículos só poderá ser feito a baixas velocidades (máximo de $40 \mathrm{~km}$ ).

A entrada do Monumento Natural até o final do Labirinto das Falésias, a faixa de praia e a lagoa do Tracuá estarão na Zona de Uso Extensivo. Estes três ambientes têm poucas alterações humanas.

Nas falésias, o que se encontra modificado pela ação humana são apenas as antigas inscrições feitas nas falésias, antes do decreto de instituição da unidade de conservação.

A faixa de praia (sem ocupação) não tem alterações. O que se verifica é apenas a presença de uma barraca que vende água de côco, refrigerantes para os turistas, quando eles saem do Labirinto. O local é onde os bugueiros esperam pelas pessoas que fazem os passeios.

A lagoa do Tracuá também não possui alterações antrópicas significativas, pois é utilizada como lazer para a comunidade do Morro Branco e Tracuá.

Ressalta-se que as áreas explicitadas acima são as mais acessadas pelos visitantes e moradores do Monumento Natural (principalmente a faixa de praia) e que o Labirinto é a única trilha existente na unidade de conservação, tendo portanto mais facilidade de acesso, é a área mais utilizada dentro do Monumento. A Zona de Uso Extensivo tem uma área de 40,9 hectares.

Zona de Uso Especial (ZUES): Esta zona é destinada às áreas que são necessárias à administração, manutenção e serviços da Unidade de Conservação como habitações, oficinas etc.

Estas áreas serão escolhidas e controladas de forma a não conflitarem com seu caráter natural e devem localizar-se, sempre que possível, na periferia da Unidade de Conservação. 0 objetivo geral do manejo é minimizar o impacto da implantação das estruturas ou os efeitos das obras no ambiente natural ou cultural da unidade.

Incluiu-se nessa zona, a área da comunidade do Morro Branco, pois lá poderá ser construído um centro de visitantes que servirá como um apoio para a administração da UC (o centro de visitantes será abordado no tópico sobre melhoria de infra-estrutura e diretrizes para o turismo), uma vez que a comunidade se encontra mesmo do lado da entrada do Monumento.

Resolveu-se incluir na ZUES a faixa de praia e pós-praia que se encontra ocupada e 0

Geografia Ensino \& Pesquisa, v. 16, n.2 p. 129 - 145, maio/ago. 2012

\footnotetext{
Planejamento ambiental em uma unidade de conservação no município de Beberibe - Ceará
} tabuleiro pré-litorâneo. As atividades desenvolvidas nestas áreas serão mais controladas, evitandose assim um aumento de barracas, as quais poderiam adentrar a faixa de praia sem ocupação (que se encontra na zona de uso extensivo) e evitando também uma expansão desordenada do tabuleiro, desta forma as atividades de infra-estrutura ficarão mais reguladas. Esta zona tem uma área de 207,7 hectares. As normas gerais desta zona são:

- As instalações desta zona preferentemente deverão estar localizadas na periferia da Unidade;

- As construções e reformas deverão estar em harmonia com o meio ambiente; 
- A fiscalização e o monitoramento serão realizados de forma permanente;

- Os veículos deverão transitar em baixas velocidades e será proibido o uso de buzinas.

- Os esgotos deverão receber tratamento suficiente para não contaminarem rios, riachos ou nascentes.

Com as propostas apresentadas o Monumento ficará mais protegido. Com as recomendações feitas na Praia das Fontes, que serão apresentadas a seguir, todo o entorno próximo ao Monumento será beneficiado. Tanto a praia das Fontes ficará mais defendida contra os avanços da especulação imobiliária como o Monumento que, com a zona de amortecimento delimitada, ficará mais difícil de ser degradado ambientalmente. Haverá desta forma, uma integração mútua das áreas, já que se pretende propor uma Área de Proteção Ambiental da Praia das Fontes.

\section{Zoneamento Ambiental da Praia das Fontes}

Para o Zoneamento Ambiental da APA utilizaram-se os critérios adotados pelo IBAMA (2001) em seu "Roteiro Metodológico para Gestão de Áreas de Proteção Ambiental" e trabalhos de Cardoso (2002) e Vidal (2006).

Importante ressaltar é que no contato das unidades geoambientais pertencentes a APA e das unidades que integram a zona de amortecimento do Monumento Natural, o tipo de uso delas são iguais, de proteção máxima. Como na praia das Fontes há a presença maciça de hotéis e casas de veraneio, neste setor haverá uma zona específica dentro do zoneamento que será discutido do decorrer da proposta de zoneamento.

As zonas estabelecidas para a APA da Praia das Fontes são:

Zona de Preservação Ambiental (ZPA): As unidades da faixa de praia, pós-praia, dunas móveis e as falésias sem ocupação estão incluídas nesta zona. 0 objetivo da ZPA é a preservação integral da biodiversidade, da estabilidade geomorfológica e dos aspectos paisagísticos.

Nestas zonas de proteção adota-se postura de controle muito rigorosa para os espaços ambientais com níveis elevados de conservação ou fragilidade e para territórios considerados fundamentais para expansão ou conservação da biodiversidade (IBAMA, 2001).

Devido às próprias condições sócio-econômicas do local, fica difícil proibir a retirada de barracas na pós-praia, pois as mesmas pertencem aos moradores, tornando-se um meio de sustento das famílias locais. Segundo o IBAMA (2001) nos setores já alterados nesta zona poderão se admitir um nível de utilização, mas com normas bastante rigorosas.

As dunas móveis que ainda não se encontram ocupadas estão localizadas atrás de áreas urbanizadas em dunas móveis. Com a proteção ambiental, estas unidades não serão ocupadas futuramente. É importante que os loteamentos feitos nas dunas sejam retirados, pois não se sabe como conseguiram os terrenos para as construções.

As falésias sem ocupações antrópicas ocorrem em pequenas proporções, geralmente são as falésias onde as fontes de água se localizam, se encontram mais no final da praia das Fontes.

Dentre as atividades que podem ser realizadas na área estão a pesquisa científica, lazer, monitoramento e educação ambiental. A ZPA tem uma área de 163,4 hectares.

Zona de Conservação Ambiental (ZCA): 0 objetivo desta zona é o manejo correto dos atributos naturais, podendo conter ocupações, desde que sejam respeitadas as condições naturais do terreno. Pertencem a ZCA, a lagoa da Uberaba, os pequenos córregos e as dunas fixas.

A lagoa da Uberaba é mais usada para o abastecimento feito pela CAGECE, além de propiciar o lazer para a população local. O que se recomenda é um programa de monitoramento da qualidade da água, evitando-se os riscos de poluição.

As dunas fixas contêm espécies arbóreas que servem de alimentos para a população como o Anacardium occidentale (caju), Byrsonima spp (murici), dentre outros. Recomenda-se o uso sustentável destas espécies, para que se continue garantir a manutenção das dunas como também

Geografia Ensino \& Pesquisa, v. 16, n.2 p. 129- 145, maio/ago. 2012

Silva, J. M. O.; Silva, E. V.

ISSN 2236-4994 
dos frutos que a vegetação oferece. De acordo com Cardoso (2002) a implantação das dunas fixas na zona de conservação ambiental servirá para atividades de Ecoturismo e estudos científicos por escolas e universidades feitos em grupos pequenos de visitantes, transformando-a em um laboratório natural. AZCA tem uma área de 92,1 hectares.

Área de Ocorrência Ambiental (AOA): Esta área foi adotada aqui por causa da Gruta da Mãe D'água. A gruta apresenta características que se enquadram nesta categoria. De acordo com IBAMA (2001) a Área de Ocorrência Ambiental são áreas de pequena dimensão territorial que apresentam situações físicas e bióticas particulares, ocorrendo de forma dispersa e generalizada em quaisquer das zonas ambientais estabelecidas. São passíveis de enquadramento nesta categoria as Áreas de Preservação Permanente (APP) e Áreas de Proteção Especial (APE).

A gruta da Mãe D'água é considerada uma APP por constituir-se de bordas de escarpas, de acordo com as categorias de APP do CONAMA. A gruta possui uma pequena dimensão, situação física bem particular (é a única "caverna" escavada pela ação do mar nas falésias no litoral de Beberibe). Está em uma das zonas estabelecidas (Zona de Preservação, pois está no contato da faixa de praia e das falésias - esta unidade geomorfológica se enquadra na Zona de Recuperação Ambiental). AAOA tem uma área de 0,5 hectares. Deve-se monitorar a gruta, evitando degradações semelhantes às existentes no Labirinto (inscrições nas paredes), antes do decreto do Monumento Natural. As atividades permitidas são as pesquisas científicas, lazer, visitas, educação ambiental.

Zona de Recuperação Ambiental (ZRA): Destina-se a recuperação de áreas que foram degradadas. Incluem-se nesta zona as falésias que foram ocupadas e que ainda permitem a visualização destas estruturas, assim como as dunas móveis que foram aterradas para a ocupação e as que comportam o Parque Eólico.

Nas falésias mortas que perderam a sua vegetação para as construções, percebe-se em alguns pontos a presença de lixo e marcas de vossorocamento. É importante que se faça um trabalho de replantio da vegetação natural e coleta adequada do lixo.

A parte das dunas que foi ocupada precisa de cuidado para que as mesmas se recuperem, já que as mesmas ainda abrigam condições naturais. As dunas do Parque Eólico precisam de um trabalho de monitoramento que procure estudar a sua dinâmica natural após a implantação do Parque, evitando futuros problemas. A ZRA tem uma área de 66,9 hectares.

Zona de Ocupação Urbana (ZOU): A ZOU inclui as áreas dentro da APA que estão ocupadas. Segundo Cardoso (2002) para as áreas presentes na Zona de Ocupação Urbana deve-se melhorar a qualidade paisagística e sanitária bem como as atividades sócio-econômicas e de lazer. A ZOU divide-se em duas áreas, por causa das diferentes ocupações na área: a Zona de Ocupação Especial (ZOE) e a Zona de Ocupação Residencial e Hoteleira (ZORH).

Zona de Ocupação Especial (ZOE): Esta zona abriga a comunidade da Praia das Fontes. Designase especial em virtude da região ter sido habitada pelos antepassados da comunidade local. Deve-se, portanto dar a posse definitiva da terra, evitando futuros problemas com a especulação imobiliária. Com a posse, também ficaria proibida a venda da casa, podendo morar no local as pessoas que tenham parentesco com a comunidade. A Zona de Uso Especial, se colocada em prática, melhorará tanto as condições sociais como naturais da Praia das Fontes. AZOE tem uma área de 4 hectares.

Zona de Ocupação Residencial e Hoteleira (ZORH): Esta zona abriga as ocupações das casas de veraneios e hotéis da área. Como é impossível a retirada destas construções nas dunas e falésias onde foram instaladas, é necessária uma rigorosa fiscalização para que não se permita novas construções. Fazer um levantamento para saber se há um sistema de esgoto que não esteja p. 129 - 145, maio/ago. 2012

Planejamento ambiental em uma unidade de conservação no município de Beberibe - Ceará

142

ISSN 2236-4994 poluindo o local e punir os infratores. Os usuários desta zona deverão respeitar os seus limites, não podendo utilizar de forma incorreta os recursos naturais das outras zonas e nem da sua. A ZORH não tem um tamanho de área específico, por causa da ocorrência de casas de veraneio e hotéis acontecer de forma dispersa, não se localizando em um só lugar, como ocorre na comunidade local, o que torna difícil mensurar a área. 

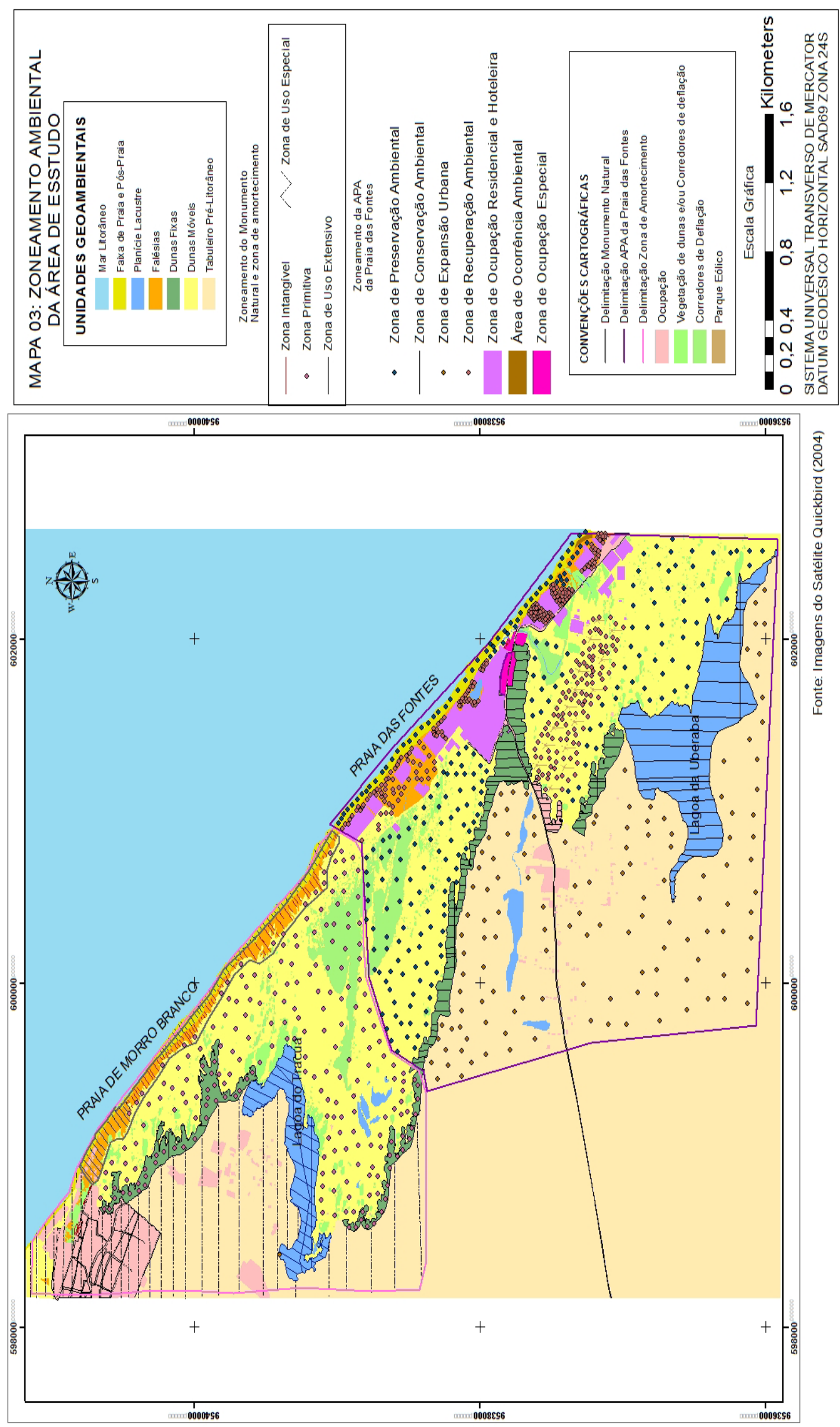

Geografia Ensino \& Pesquisa, v. 16, n.2 p. 129- 145, maio/ago. 2012

Silva, J. M. O.; Silva, E. V. 
Zona de Expansão Urbana (ZEU): Destinada para novas construções, mas em conformidade com a lei e as condições naturais do terreno. O tabuleiro pré-litorâneo, por apresentar uma estabilidade ambiental maior, poderá abrigar novas construções, mas de forma que não comprometa a capacidade de suporte da área e sem comprometer as condições sócio-econômicas da população da comunidade do Onofre, que reside na localidade.

\section{Conclusões}

Este zoneamento, assim como o que foi proposto para o Monumento Natural, poderá ser discutido juntamente com os setores que se encontram envolvidos na Praia das Fontes. 0 que se procurou fazer aqui foi uma contribuição para o processo de planejamento e gestão da área interna e externa da Unidade de Conservação em estudo, buscando conciliar o meio ambiente com as atividades sócio-econômicas do local. A Cartografia foi importante, pois auxiliou na delimitação das unidades geoambientais e para a proposta de zoneamento da área.

Espera-se que este trabalho tenha contribuindo para as pesquisas referentes a temática e que as sugestões aqui apresentadas possam ser aproveitadas para a melhoria da gestão ambiental da Unidade de Conservação e do próprio entorno que ela abrange. Desta forma, tanto o Monumento Natural como o espaço ao redor da UC possam ser administrados de acordo com as potencialidades geoambientais da área em comunhão com todos os atores envolvidos na questão ambiental das praias de Morro Branco e das Fontes.

\section{Referências}

BERTRAND, G. Paisagem e Geografia Física Global: esboço metodológico. Caderno de Ciências da Terra, USP, Instituto de Geografia. São Paulo, 1972.

CAMARGO, A.F; SOARES, R.P. Avaliação temporal do uso da terra com imagens do satélite landsat sensores tm e etm+, no município de Giruá -RS. In: XII Simpósio Brasileiro de Geografia Física Aplicada. Natal: Anais do XII Simpósio Brasileiro de Geografia Física Aplicada, 2007.

CARDOSO, E.S. Análise das condições ambientais do litoral de Iguape e Barro Preto. Programa de Desenvolvimento e Meio Ambiente (PRODEMA), Universidade Federal do Ceará: Fortaleza, 2002. (Dissertação de Mestrado).

CPRM. Atlas digital de geologia e recursos minerais do Ceará. Companhia de Recursos Minerais do Brasil. Ceará: 2004.

FALCÃO-SOBRINHO, F; FALCÃO, C.L.C. Geografia Física: a natureza na pesquisa e no ensino. Rio de Janeiro: TMAISOITO, 2008.

GUERRA, A.J.T; MARÇAL, M. Geomorfologia Ambiental. Rio de Janeiro: Bertrand Brasil, 2006.

Geografia Ensino \& Pesquisa, v. 16, n.2 p. 129 - 145, maio/ago. 2012

\footnotetext{
Planejamento ambiental em uma unidade de conservação no município de Beberibe - Ceará
}

IBAMA. Roteiro Metodológico de Planejamento - Parque Nacional, Reserva Biológica, Estação Ecológica. Ministério do Meio Ambiente. Brasília: IBAMA, 2002.

IBAMA. Roteiro Metodológico para gestão de Áreas de Proteção Ambiental. Ministério do Meio Ambiente. Brasília: IBAMA, 2001.

OLIVEIRA, A.L.C; MARQUES, J.S. Uma visão geográfica sobre Unidades de Conservação: o caso do município do Rio de Janeiro. In: Anais do X Simpósio Brasileiro de Geografia 
Física Aplicada. Rio de Janeiro, 2003. pág. 995-2002.

ROSS, J. L. S. Ecogeografia do Brasil. 1. ed. São Paulo: Oficina de Textos, 2006. v. 1. 208 p.

SANTOS, R.F. Planejamento Ambiental: Teoria e Prática. São Paulo: Oficina de textos, 2004.

SEMACE. Diagnóstico Sócio-Ambiental do Município de Beberibe. Superintendência Estadual do Meio Ambiente. Fortaleza: 2003.

SILVA, J. B. ; Cavalcante, T. C. ; VERISSIMO, M. E. Z. ; CASTELO, R. Atlas do Ceará. 2. ed. João Pessoa: Grafiset, 2004. v. 1. 200 p.

SILVA, J.M.O. Monumento Natural das Falésias: diretrizes para o planejamento e gestão ambiental. Fortaleza: Universidade Federal do Ceará, Programa de Pós-Graduação em Geografia, 2008. (Dissertação de Mestrado).

SNUC. Congresso. Senado. Lei $\mathbf{n}^{\circ}$ 9.985, de 18 de julho de 2000. Regulamenta 0 art. 225, § 01 , incisos I, II, III e VII da Constituição Federal, institui o Sistema Nacional de Unidades de Conservação da Natureza e dá outras providências. Diário Oficial [da] República Federativa do Brasil, Brasilia, DF, 18 julho, 2000.

SOARES, A.M.L. Zoneamento geoambiental do Município de Beberibe. Dissertação de Mestrado, Universidade Estadual do Ceará, 1998.

VIDAL, M.R. Proposta de Gestão Ambiental para a RESEX do Batoque. Programa de Pós-Gradução em Geografia, Universidade Federal do Ceará: Fortaleza, 2006. (Dissertação de Mestrado).

\section{Correspondência:}

Juliana Maria Oliveira Silva - Rua Diamantina 33, Bairro Joquei Clube. Fortaleza-Ceará. Cep: 60440-190

E-mail: julianageografiaufc@yahoo.com.br

Recebido em 30 de janeiro de 2012.

Revisado pelo autor em 10 de julho de 2012.

Aceito para publicação em 30 de julho de 2012. 